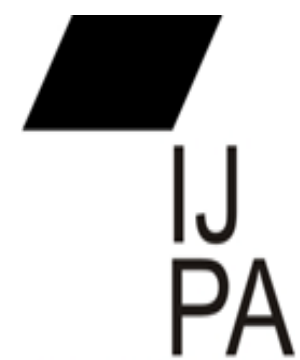

ISSN $2460=0369$

\section{RELASI AKTOR DALAM IMPLEMENTASI KEBIJAKAN PENDIDIKAN MENENGAH DI KOTA MATARAM}

\author{
Muhammad Ali \\ Dosen Administrasi Publik \\ Universitas Muhammadyah Mataram Nusa Tenggara Barat \\ muhamadali@gmail.com
}

\begin{abstract}
Secondary education policy needs to be improved by a process which is a strategic alternative to improve the quality of education. This paper examines the relation of actors in the implementation of secondary education policy in the city of Mataram which focuses on senior secondary education as an education sub-system by formulating and implementing education-related policies that are trademarks for the achievement of policy objectives. The Key to Policy Implementation uses a participatory approach in public policy making in education supported by 4 (four) factors as a driver of successful policy implementation. But in reality there are causes of the implementation of policies that have not optimally reached their objectives, namely: a). Communication b). Resources (Resources), c). Implementor Attitudes (Dispositions), and d). Bureaucratic Structure (Bureaucratic Structure). Then, on the other hand, the Government's relation with actors outside the government is not yet optimal, where the government has not effectively built relationships with the community and the business world so that governance has not been created in the implementation of secondary education policies. This condition requires improvement of aspects of policy implementation and improvement of coordination between actors and organizational culture towards the achievement of secondary education policy objectives in supporting governance in the city of Mataram.
\end{abstract}

Keywords: Policy Implementation, Secondary Education, Governance

\begin{abstract}
Abstrak, Kebijakan pendidikan menengah perlu ditingkatkan dengan suatu proses yang merupakan alternatif strategis untuk meningkatkan kualitas pendidikan. Tulisan ini mengkaji relasi aktor dalam implementasi kebijakan pendidikan menengah di kota mataram yang menitikberatkan pada pendidikan menengah atas sebagai sub sistem pendidikan dengan merumuskan dan melaksanakan kebijakan terkait pendidikan yang menjadi trademark unttuk tercapainya tujuan kebijakan. Kunci Implementasi kebijakan menggunakan pendekatan partisipatory dalam pengambilan kebijakan publik bidang pendidikan yang ditopang oleh 4 (empat) faktor sebagai pendorong keberhasilan implementasi kebijakan. Namun secara realitas adanya penyebab implementasi kebijakan yang belum secara optimal mencapai tujuannya yaitu: a). Komunikasi b). Sumber Daya (Resources), c). Sikap Implementor (Dispositions), dan d). Struktur Birokrasi (Bureaucratic Structure). Kemudian pada sisi yang lain relasai Pemerintah dengan aktor di luar pemerintah yang belum optimal, dimana pemerintah belum secara efektif membangun relasi dengan masyarakat dan dunia usaha sehingga belum tercipta governance dalam implementasi kebijakan pendidikan menengah. Kondisi ini memerlukan pembenahan terhadap aspek-aspek implementasi kebijakan dan peningkatan koordinasi antar aktor dan budaya organisasi ke arah pencapaian tujuan kebijakan pendidikan menengah dalam mendukung governance di kota Mataram.
\end{abstract}

Kata Kunci: Implementasi Kebijakan, Pendidikan Menengah, Governance 


\section{PENDAHULUAN}

Pendidikan sangat penting bagi kelangsungan hidup sebuah negara/ bangsa. Untuk memperoleh sumber daya manusia unggul dibutuhkan proses pendidikan yang baik. Proses pendidikan yang baik bukan hanya menjadi tanggung jawab lembaga penyelenggara pendidikan semata, tetapi didukung perannya oleh masyarakat, swasta dan pemerintah yang dalam hal ini bertindak sebagai pemegang amanah tertinggi dari UUD 1945 untuk mencerdaskan kehidupan bangsa Indonesia.

Karena itu, reformasi di Indonesia menuntut otonomi daerah yang secara bertahap kewenangan kebijakan pendidikan diserahkan kepada pemerintah daerah, artinya bahwa ada keleluasaan kepada daerah untuk menjalankan aktivitas pelayanan publik bidang pendidikan tanpa harus banyak terpaku pada aturan-aturan yang telah dibuat oleh pemerintah pusat.

Kebijakan pendidikan di daerah dalam konteks otonomi daerah melalui kebijakan desentralisasi yaitu dengan diterbitkannya Undang-Undang Nomor 23 Tahun 2014 bahwa urusan pemerintah yang diserahkan kepada daerah disertai dengan sumber pendanaan, pengalihan sarana dan prasarana, serta kepegawaian sesuai dengan urusan yang di desentralisasikan, dan kebijakan pendidikan nasional berdasarkan UndangUndang Nomor 20 tahun 2003. Implementasi kebijakan memerlukan regulasi yang jelas, menyaratkan adanya tata kelola yang baik antara pemerintah, swasta dan masyarakat. Selain itu juga diperlukan kejelasan pola komunikasi inter organisasi, sehingga tujuan yang di inginkan tercapai. Upaya dalam pencapaian standar dan sasaran kebijakan menjelaskan tujuan keputusan kebijakan secara menyeluruh dalam berbagai kegiatan.

Jika dikaitkan dengan pandangan Edward III (1980) yang menyoroti implementasi kebijakan publik, lebih menekankan keberhasilan implementasi kebijakan pada bidang apapun termasuk di dalammnya bidang pendidikan, memerlukan dukungan yang meliputi (a) communication, (b) resources, (c) dispotition, dan (d) structur bureaucration. Keempat aspek/variabel implementasi kebijakan ini turut menentukan keberhasilan implementasi kebijakan publik. Pada sisi yang lain jika keempat aspek/variabel implementasi kebijakan ini diabaikan maka akan menghambat keberhasilan implementasi kebijakan. 
Pada sisi yang lain, emprical problem terkait dengan implementasi kebijakan pendidikan menengah di Kota Mataram yang jika dilihat dari aspek komunikasi terlihat masih minimnya sosialisasi kebijakan-kebijakan yang dihasilkan baik makro maupun mikro kepada pemangku kepantingan, sehingga seringkali menimbulkan permasalahan dalam memahami kebijakan yang berbasis pendidikan menengah di Kota Mataram. Pada aspek sumberdaya menunjukkan bahwa masih memiliki kelemahan dan keterbatasan. Sumberdaya aparatur sebagai implementor/pelaksana kebijakan pendidikan menengah Kota Mataram memiliki kelemahan baik jumlah yaitu aparat yang ada di Dinas pendidikan dan Olaharga yang memiliki tugas dan fungsi secara langsung dengan implementrasi pendidikan menengah, yaitu Bidang Pendidikan Menengah yang kualitas pendidikannya masih rendah dengan ketrampilan yang belum memadai. Kemudian terkait dengan alokasi dana pendidikan dinilai belum memadai, hal ini disebabkan sumber dana dari Anggaran Pendapatan Belanja Daerah (APBD) Kota Mataram belum mencukupi untuk membiayai penyelenggaraan pendidikan menengah Kota Mataram, sehingga memerlukan dukungan dana yang bersumber dari Anggaran Pendapatan Belanja Negara (APBN) dan partisipasi masyarakat dalam membiayai pendidikan.

Aspek disposisi dari implementasi kebijakan dinilai masih memiliki kelemahan, yang menunjukan bahwa perilaku aparat birokrasi sebagai pelaksana kebijakan belum begitu memihak kepada masyarakat sebagai pemangku kepentingan, akan tetapi selalu berpihak kepada para elit baik politik maupun birokrasi. Kepentingan-kepentingan elit selalu dinomor satukan, jika dibandingkan dengan masyarakat sebagai pemilik kedaulatan yang harus dilayani. Pada aspek struktur birokrasi terkesan masih birokratis dan panjang hirarchinya, dengan prinsip komando/perintah secara organisatoris dari level atas sampai pada level sekolah.

Implementasi kebijakan memerlukan regulasi yang jelas, menyaratkan adanya tata kelola yang baik antara pemerintah, swasta dan masyarakat. Selain itu juga diperlukan kejelasan pola komunikasi inter organisasi, sehingga tujuan yang di inginkan tercapai. Upaya dalam pencapaian standar dan sasaran kebijakan menjelaskan tujuan keputusan kebijakan secara menyeluruh dalam berbagai kegiatan. Kegiatan ini melangkah dari tingkat kebijakan berwujud dokumen peraturan menuju penentuan standar spesifik dan kongkrit untuk menilai kinerja program. Standar dan sasaran tercapai jika dinyatakan 
dengan tingkat kejelasan yang memadai, sehingga peranan pelaksana dalam memahami apa yang diharapkan dari program. Pada tingkat ini, telaah terhadap proses implementasi menjadi sangat penting, pihak-pihak berkepentingan mana saja yang terlibat dalam proses implementasi dan seberapa besar keterlibatannya. Pendekatan untuk memahami proses implementasinya serta menilai hasilnya secara bersama-sama merupakan suatu proses pembelajaran bagi keberhasilan implementasi kebijakan program.

Kondisi ini menujukkan bahwa implementasi kebijakan pendidikan menengah di Kota Mataram dinilai belum optimal.

\section{KAJIAN TEORITIS}

Pemahaman tentang berbagai faktor yang terkait implementasi, dielaborasi beberapa teori implementasi kebijakan dan dijadikan sebagaii landasan pijak dalam kajian ini. Implementasi kebijakan adalah hal yang paling krusial, karena seringkali masalah-masalah yang kadang tidak dijumpai dalam konsep, muncul di lapangan. Selain itu ancaman utama implementasi adalah ketidak konsistensi implementasi.

Model implementasi yang dikembangkan oleh George C. Edwards III (1980:16-20) yang disebut dengan Direct and Indirect Impact of Implementation sebagai rujukan dalam mengkaji implementasi kebijakan publik. Terdapat empat variabel yang sangat menentukan keberhasilan suatu kebijakan, yaitu: (a) Komunikasi; (b) Sumber Daya; (c) Disposisi; dan (d) Struktur Birokrasi. Model ini menggariskan implementasi kebijakan berjalan secara linier dari komunikasi, sumber daya politik yang tersedia dan pelaksanaan implementasi kebijakan. Dalam pandangan Sabatier dikutip Akib (2004), terdapat dua model yang berpacu dalam tahap implementasi kebijakan, yaitu model top down dan model bottom up. Kedua model ini terdapat pada setiap proses pembuatan kebijakan. Sabatier dan Mazmanian (1983) berpendapat bahwa peran penting dari analisis implementasi kebijakan ialah mengidentifikasikan variabelvariabel yang mempengaruhi tercapainya tujuan-tujuan formal pada keseluruhan proses implementasi.

Implementasi sebagai faktor yang mempengaruhi aktivitas implementasi yang menurut Grindle (1980) mencirikan adanya interaksi antara pengambil kebijakan, pelaksana kebijakan dan pengguna kebijakan dalam model interaktif. Dalam perspektif Grindle, (1980) selain menunjukkan dominasi cirinya yang cenderung lebih dekat 
kepada ciri model interaktif implementasi kebijakan, juga menunjukkan kelebihan model tersebut dalam cara yang digunakan untuk mengukur keberhasilan implementasi kebijakan, beserta output dan outcomesnya. (Akib dan Tarigan, 2004). Sementara dalam pandangan Van Meter dan Van Horn (1978) mengembangkan Model Proses Implementasi Kebijakan yang lebih melihat kontrol dan kepatuhan dalam bertindak merupakan konsep penting dalam prosedur implementasi.

Quade (1984: 310), untuk mengukur kinerja implementasi suatu kebijakan publik harus memperhatikan variabel kebijakan, organisasi dan lingkungan. Perhatian itu perlu diarahkan karena melalui pemilihan kebijakan yang tepat maka masyarakat dapat berpartisipasi memberikan kontribusi yang optimal untuk mencapai tujuan yang diinginkan. Ripley dan Franklin (1986:12) mendasarkannya pada tiga aspek, yaitu: (1) tingkat kepatuhan birokrasi sesuai undang-undang, (2) adanya kelancaran rutinitas dan tidak adanya masalah; serta (3) pelaksanaan dan dampak (manfaat) yang dikehendaki dari semua program yang ada terarah. Sedangkan menurut Goggin et al. (1990: 20-40): proses implementasi kebijakan sebagai upaya transfer informasi atau pesan dari institusi yang lebih tinggi ke institusi yang lebih rendah diukur keberhasilan kinerjanya berdasarkan variabel: (1) dorongan dan paksaan pada tingkat federal, (2) kapasitas pusat/negara, dan (3) dorongan dan paksaan pada tingkat pusat dan daerah. Keberhasilan implementasi kebijakan yang oleh Syamsiar (2005), perlu dikaitkan dengan governance sebagai faktor paling penting untuk mencapai tujuan kebijakan atau organisasi, tidak jelas apakah rujukannya ke struktur organisasi, proses administrasi secara jelas dan pasti yang merupakan penemuan kembali pemerintahan yang dikelola secara baik. Governance pada dasarnya merupakan paradigma baru yang melibatkan bukan hanya pemerintah atau negara, tetapi juga peran berbagai aktor di luar pemerintahan dan negara, sehingga pihak-pihak yang terlibat sangat luas (Dwiyanto, 2004).

\section{METODE PENELITIAN}

Penelitian ini bertujuan untuk menggambarkan, dan menganalisis fenomena yang berkaitan dengan implementasi kebijakan pendidikan menengah dalam perspektif governance dilingkungan SMA Negeri Kota Mataram, dengan menggunakan pendekatan kualitatif, untuk mengungkap realitas yang terjadi dilapangan secara menyeluruh, baik yang nyata maupun yang tersembunyi. Fokus penelitian ini adalah 
implementasi kebijakan pendidikan menengah khususnya penyelenggaraan pendidikan di lingkungan SMA Negeri Kota Mataram., pada aspek Semangat Governance (Relasi Pemerintah, dunia usaha dan masyarakat) dalam implementasi kebijakan pendidikan menengah di Kota Mataram. Sumber data yang dikumpulkan sesuai dengan fokus penelitian ini adalah informan, peristiwa, dan dokumentasi. Teknik pengumpulan data yang digunakan dalam penelitian ini adalah: Wawancara, Observasi, Dokumentasi, FGD. Tehnik analisis data dengan menggunakan model analisis kualitatif yaitu model analisis interaktif, dengan tiga komponen berupa reduksi data, sajian data, serta penarikan kesimpulan/verifikasi dengan menggunakan proses siklus.

\section{PEMBAHASAN}

\section{Relasi antar aktor dalam implementasi kebijakan pendidikan menengah di Kota Mataram}

Sejumlah terobosan yang diluncurkan dalam membangun Kota Mataram, tidak hanya persoalan penataan fisik kota seperti revitalisasi pasar, penataan hunian liar, hingga fasilitas-fasilitas pelayanan, pembangunan nonfisik juga banyak dilakukan. Misalnya dibidang pelayanan perizinan, kesehatan dan pemberdayaan masyarakat akan tetapi pada aspek pendidikan.

Usaha-usaha tersebut seolah-olah ingin membuktikan keunggulan lain kota ini dalam hal kompetensi sumber daya manusianya. Program-program yang digagas pemerintah adalah program inovatif daerah yang bertujuan untuk memenuhi kebutuhan masyarakat. Program-program inovatif tersebut diperlukan sebagai bagian dari proses perubahan birokrasi pendidikan. Paradigma lama yang bercirikan pendidikan yang hanya mentransfer ilmu sebagai mesin yang dijalankan atas dasar perintah kini diubah dengan memfokuskan tujuannya pada hasil dan kinerja yang dicapai.

Bila diamati, hanya sedikit daerah yang mampu melakukan langkah-langkah terobosan secara intensif sebagaimana dilakukan Kota Mataram yang diluncurkan Walikota seolah menyiratkan keinginan pemerintah kota Mataram meningkatkan kesejahteraan masyarakatnya lewat dunia pendidikan, terutama melalui programprogram pembangunan yang kreatif. Fakta menunjukkan bahwa daerah-daerah yang kurang kreatif biasanya relatif lambat, bahkan bisa mengalami stagnan. Sulit untuk menangkap peluang yang ada, karena hanya sibuk berkutat pada pekerjaan rutinnya saja. Sudah pasti daerah yang kurang berkembang pada gilirannya akan merugikan 
masyarakatnya. Lapangan pekerjaan dan kesempatan berusaha terbatas jumlahnya. Demikian pula keterbatasan dalam pemenuhan sarana dan prasarana umum.

Strategi Pemerintah Kota Mataram dalam menumbuh kembangkan kreativitas pembangunan pendidikan menengah bukannya tanpa resiko. Jika tidak bijak dan terencana baik, langkah kreatif Pemerintah kota Mataram itu bisa berbenturan dengan persoalan lain. Misalnya, benturan antara Pemerintah Kota dengan sekelompok masyarakat terkait implementasi kebijakan pendidikan. Perbedaan kepentingan yang tidak diiringi solusi konkret sering menimbulkan pertentangan. Keberanian Pemerintah Kota Mataram mengambil resiko dari program-program yang dibuatnya merupakan ciri dari pemerintahan wirausaha (Reinventing Government), dimana pemerintah lebih berperan sebagai risk-taking ketimbang hanya sebagai risk-avers. Oleh karena itulah, pemerintah mengambil langkah strategis dalam kebijakannya yaitu melakukan pendekatan partisipatory. Pendekatan partisipatory membuka jalan komunikasi dengan berbagai elemen daerah (multi stakeholder). Dengan strategi mengkolaborasikan nilai-nilai positif dari model-model implementasi kebijakan pendidikan menengah di Kota Mataram diharapkan bisa berlangsung komprehensif dan simultan. Tidak hanya membangun bidang pendidikan, juga membangun atau menyejahterakan warga. Kuncinya terletak pada bagaimana melibatkan multi stakeholders dalam proses kebijakan (formulasi, implementasi, dan evaluasi kebijakan). Melalui keterlibatan publik secara konsisten, sehingga kepentingan publik dalam pembangunan dapat direduksi. Kreativitas yang dicanangkan Pemerintah Kota Mataram juga akan lebih tepat sasaran.

Ada sejumlah prinsip yang dianggap sebagai prinsip-prinsip utama yang melandasi pelaksanaan governance di Kota Mataram, yaitu (1) pilar negara, (2) dunia usaha, dan (3) Partisipasi Masyarakat. Ketiganya tidak bisa berdiri sendiri- sendiri, sehingga mengesampingkan prinsip-prinsip yang lain. Dari ketiga prinsip tersebut, saat ini partisipasi masyarakat masih menduduki peringkat pertama dalam pelaksanaannya. Sehingga ketika sebuah daerah dalam setiap pengambilan keputusannya telah mengakomodasi partisipasi masyarakat, maka daerah tersebut dikatakan telah melaksanakan tata pemerintahan yang baik. Untuk selanjutnya, dapat diketahui bahwa esensi dari implementasi kebijakan pendidikan yang dijalankan tersebut adalah merupakan sebuah upaya untuk membangun kepercayaan (trust) masyarakat kepada 
pemerintah. Sehingga diharapkan trust ini akan memberikan legitimasi penuh kepada pemerintah agar tetap solid dan kuat dalam menjalankan tugasnya sebagai abdi rakyat.

Siapa yang harus mendapatkan hak untuk dilayani, dan siapa yang harus memegang kewajiban untuk melayani. Para pegawai pemerintah dan warga masyarakat perlu memahami apa makna kewajiban dan hak dikaitkan dengan layanan pendidikan. Pemahaman tentang kewajiban dan hak layanan publik ini sangat diperlukan, agar antara para pegawai pemerintah dan warga masyarakat sama-sama bisa menempatkan diri pada posisi yang sebenarnya, sehingga bisa menghindari terjadinya pertukaran posisi antara warga masyarakat dan para pegawai pemerintah. Pelayanan publik dibidang pendidikan yang baik mengisyaratkan upaya mendekatkan jarak antara masyarakat (public) dan pemerintah (servant). Untuk mencapai sinergitas peran tersebut tentunya harus didukung oleh pembenahan mendasar terhadap kondisi internal organisasi birokrasi itu sendiri.

Relasi antar aktor dalam hal ini pemerintah, masyarakat dan dunia usaha turut menentukan keberhasilan implementasi kebijakan. Meter dan Horn (1974) menyebutkan bahwa kondisi sosial, politik, dan ekonomi. Variable ini mencakup sumber daya ekonomi lingkungan yang dapat mendukung keberhasilan implementasi kebijakan. Mazmanian dan Sabatier (1983) bahwa terkait dengan keberhasilan implementasi kebijakan yaitu seberapa luas akses kelompok-kelompok luar untuk berpartisipasi dalam implementasi kebijakan. Suatu program memberikan peluang luas bagi masyarakat untuk terlibat relatif mendapat dukungan dari pada program yang tidak melibatkan masyarakat. Keberhasilan implementasi menurut Grindle (1980) yaitu sejauh mana kepentingan kelompok sasaran atau target groups termuat dalam isi kebijakan. Kelompok sasaran disini tidak hanya birokrasi pendidikan akan tetapi masyarakat sebagai pengguna layanan pendidikan dan dunia usaha yang turut memberikan partisipasinya dalam implementasi kebijakan pendidikan.

Sehubungan dengan sinergi antar aktor dalam governance di Kota Mataram belum begitu nampak di permukaan dan nampaknya juga masyarakat dan dunia usaha/dunia industri belum begitu peduli, namun demikian telah ada upaya-upaya ke arah itu dengan mencoba meloby pihak CSR agar bisa membantu siswa miskin, karenanya semua masyarakat mendukung pendidikan menengah terutama SMA dengan membantu penduduk miskin termasuk buta aksara yang walaupun belum tuntas, melalui 
BAZDA Kota Mataram.Interaksi antar aktor, di Kota Mataram masih kurang dirasakan.

Bagaimana relasi antar aktor dalam implementasi kebijakan pendidikan di Kota Mataram, prosesnya dapat dibahas sebagai berikut:

\section{Peranan Pemerintah}

Penyelenggaraan pendidikan di Kota Mataram dilaksanakan secara terpadu dengan melibatkan segenap stakeholder yaitu pemerintah daerah, masyarakat, dan dunia usaha/dunia industri. Pemerintah telah mengatur secara berjenjang dengan berbagai peraturan perundang-undangan, maka Kota Mataram menjadi bagian yang tidak terpisahkan dari ketentuan peraturan secara nasional yaitu Undang-Undang Nomor 20 Tahun 2003 tentang Sistem Pendidikan Nasional, Undang-Undang Nomor 14 tentang Guru dan Dosen, Peraturan Pemerintah Nomor 38 Tahun 2007 tentang Pembagian Kewenangan Antara Pusat dan Daerah, dan Peraturan Pemerintah Nomor 66 Tahun 2010 tentang Pengelolaan dan Penyelenggaraan Pendidikan.

Bidang pendidikan merupakan salah satu urusan pemerintahan yang menjadi kewenangan daerah otonom, penyelenggaraan pendidikan ini menjadi sangat penting karena merupakan salah satu fungsi pelayanan dasar masyarakat. Permasalahan pendidikan merupakan aspek penting dari daerah hingga nasional. Dalam penyusunan Rencana Pembangunan Jangka Menengah Daerah (RPJMD), terdapatnya visi pembangunan untuk membentuk pendidikan yang berkualitas.

UU Sisdiknas mengingatkan, bahwa salah satu prinsip penyelenggaraan pendidikan adalah keadilan tanpa diskriminatif. Pendidikan berdiri untuk melayani seluruh lapisan masyarakat, tanpa pandang bulu, suku, agama, kaya miskin, semua rakyat Indonesia berhak mendapatkan pendidikan yang layak dan berkualitas.

Relasi antar aktor dalam Implementasi kebijakan kebijakan pendidikan menyaratkan adanya aturan tertulis yang merupakan keputusan formal organisasi, bersifat mengikat, mengatur prilaku dengan tujuan untuk menciptakan tata nilai baru dalam masyarakat. Kebijakan menjadi rujukan utama para anggota organisasi atau anggota masyarakat dalam berprilaku dan kebijakan pada umumnya bersifat problem solving dan proaktif. Berbeda dengan Hukum (Law) dan Peraturan (Regulation), kebijakan lebih adaptif dan interpretatif, meskipun kebijakan juga mengatur "apa yang boleh, dan apa yang tidak boleh". Kebijakan juga diharapkan dapat bersifat umum tetapi 
tanpa menghilangkan ciri lokal yang spesifik. Kebijakan harus memberi peluang di interpretasikan sesuai kondisi spesifik yang ada.

Mengacu kepada strukturisasi program dan kegiatan dengan Program Sistem Informasi Manajemen Keuangan Daerah (SIMDA), maka Disdikpora Kota Mataram telah menyusun program-program pembangunan pendidikan yang dihubungkan dengan tujuan dan sasaran yang akan dicapai dalam jangka pendek maupun jangka panjang. Program-program tersebut disusun berdasarkan jenjang pendidikan dan dukungan yang diperlukan untuk kelancaran pelaksanaan program-program tersebut.

Kebijakan-kebijakan dan praktik-praktik pendidikan menengah di Kota Mataram di kontrol dengan kuat, maka tidak sulit bagi pemerintah (state) untuk memposisikan pendidikan sebagai fungsi negara yang dalam hal ini dapat dilihat pada eratnya keterkaitan antara elemen-elemen pendidikan publik dengan prinsip-prinsip yang berlaku. Sekolah-sekolah adalah unit pemerintah yang banyak melibatkan kepentingan masyarakat luas. Kepala satuan pendidikan di Kota Mataram seharusnya netral atau tidak terlibat dalam aktivitas politik, akan tetapi tidak bisa dipungkiri bahwa sebagai bawahan selalu taat kepada instruksi atasan, yang walaupun memiliki resiko.

\section{Peran Dunia Usaha}

Penyelarasan pendidikan dengan kebutuhan dunia usaha adalah Sekolah tidak dapat lagi dipikirkan sebagai suatu lembaga sosial yang berdiri sendiri, terlepas dari lembaga-lembaga sosial lain. Peranan dunia usaha dalam pendidikan merupakan sisi mata uang yang jelas keduanya tidak dapat dipisahkan. Pendidikan menghasilkan lulusan yang akan digunakan oleh dunia usaha. Artinya, kualitas hasil pendidikan akan mempengaruhi kualitas dunia usaha. Dengan ini sudah barang tentu dunia usaha tidak pantas hanya menengadahkan tangannya ke atas, menunggu turunnya kualitas lulusan yang bermutu untuk menjadi SDM-nya. Memberikan kontribusi dari dana keuntungan dunia usaha sepantasnya dapat dialokasikan untuk pendidikan.

Relasi antara aktor dapat dikemukakan dalam kondisi riil di lapangan, bahwa adanya kerja sama yang didasari atas kepercayaan antara satuan unit pendidikan dengan dunia usaha dalam hal in simpul-simpul usaha, dalam hal ini usaha jasa dan industri seperti CV/ Toko Alat Tulis Kantor, konveksi/penjahit-penjahit lokal. Dunia usaha dimaksud disini adalah para komunal pengusaha/pedagang seperti CV/toko telah lama berlangganan dengan pihak sekolah. 


\section{Peranan Masyarakat}

Dewan pendidikan dan Komite sekolah diperlukan dalam sistem pendidikan. Hal ini dapat dilihat dari pelbagai sudut pandang yang dapat dijelaskan sebagai berikut: Pertama, dari sudut ilmiah akademis. Keberadaan Dewan Pendidikan dan Komite Sekolah dalam sistem pendidikan nasional memang diperlukan. Buku bertajuk "In School We Trust" karya Deborah Meier (dalam Ketua Dewan Pendidikan Kota Mataram), mengisyaratkan tentang hubungan sinergis antara sekolah dengan orang tua dan masyarakat, keberadaan Dewan Pendidikan dan Komite Sekolah memiliki landasan yang cukup kuat dari aspek ilmu pengetahuan dan akademis. Kedua, dari aspek hukum dan perundang-undangan di Indonesia. Kebijakan tentang Dewan Pendidikan dan Komite Sekolah ini sebenarnya memiliki landasan hukum yang kuat, karena keberadaan Dewan Pendidikan dan Komite Sekolah merupakan amanat undang-undang, bukan hanya amanat Keputusan Menteri Pendidikan Nasional.

Peran masyarakat seperti Dewan pendidikan Kota Mataram dan Komite Sekolah berperan aktif dalam monitoring implementasi kebijakan pendidikan seperti memfasilitasi aspirasi lapisan masyarakat dalam kebijakan pendidikan dalam hal ini formulasi dan analsis kebijakan pendidikan dan monitoring Perwal Kota Mataram terkait PPDB sistem online sekaligus Juknis pelaksanaan PPDB sistem online pada SMP, SMA dan SMK Kota Mataram telah dilaksanakan sejak tahun pelajaran 2014/2015 dengan nomor 188.4/1173/A/Dikpora/2014. Monitoring Juknisnya PPDB jalur Bina lingkungan, danPerwal No. 18 Tahun 2014 tentang Pembiayaan dan Pengelolaan Dana Pendidikan yang Bersumber dari Peran Serta Masyarakat dan Orang Tua Peserta Didik. Kebijakan-kebijakan ini memberikan semangat dalam meningkatkan kualitas pendidikan di Kota Mataram, namun karena telah berjalan kurang lebih 6 tahun, tentu membutuhkan evaluasi untuk disesuaikan tuntutan perubahan di bidang pendidikan.

Dewan Pendidikan dan Komite Sekolah merupakan wadah peran serta masyarakat untuk meningkatkan mutu layanan pendidikan di daerah dan sekolah. Dalam masyarakat tersebut banyak sekali komponen masyarakat yang dapat diajak bekerjasama untuk meningkatkan mutu pelayanan pendidikan. Dewan Pendidikan juga dapat melakukan kerjasama dengan berbagai institusi di tingkat kabupaten/kota. 
Keberadaan Komite Sekolah harus bertumpu pada landasan partisipasi masyarakat dalam meningkatkan kualitas pelayanan dan hasil pendidikan di satuan pendidikan/sekolah.

\section{KESIMPULAN}

Relasi aktor dalam implementasi kebijakan pendidikan menengah di kota Mataram kemampuan kepala daerah untuk bersinergi dengan masyarakat dan dunia usaha agar program-program yang ditetapkan dan dampaknya dapat dirasakan secara langsung oleh masyarakat belum mewujud. Kemampuan ini berkaitan dengan bagaimana Walikota (kepala daerah) memanage sumber daya yang dimilikinya sebagai implementor. Kemampuan dimaksud dapat dilihat dari peranan pemerintah, peranan dunia usaha, peranan masyarakat.

Relasi aktor di Kota Mataram masih didominasi oleh birokrasi pendidikan, dalam hal ini aparat Disdikpora Kota Mataram dan tenaga guru pada satuan pendidikan menengah umum di Kota Mataram. Aktor-aktor lain yaitu dunia usaha dan masyarakat kurang diberi peran dalam implementasi kebijakan pendidikan menengah di Kota Mataram, sehingga seringkali banyak program pendidikan yang tidak dapat di implementasikan, disebabkan karena keterbatasan sumber daya aparatur.

\section{DAFTAR PUSTAKA}

Al-Arasy Wahyuddin, 2013 : "Relasi Pemerintah, sector Swasta dan Masyarakat dalam Mengatasi Masalah Kemiskinan" diunduh melalui https://elarasy.blogspot.co.id/2013/05/relasi-antara-pemerintah-sektorswasta.html $(12 / 16 / 2017)$

Bakry, Aminuddin. 2010. Kebijakan Pendidikan Sebagai Kebijakan Publik. Jurnal Medtek Vol.2 No. 1. April.

Chema dan Rondinelli (UNCRD) 1981. "Analysing Decentralization Policies in. Developing Countries : a Political Economy" Sage Publication, London

Dolbeare Kenneth M 1975 : "Public policy evaluation; with a section on crime control evaluation" edited by John A. Gardiner.

Edward III, George, 1980. Implementing Public Policy. Washinton DC, Congresional Quaartely Press.

Fattah, Nanang. 2012. Analisis Kebijakan Pendidikan, Penerbit Remaja Rosdakarya Bandung. 
Grindle, Merilee S, 1980. Politic and Policy Implementation in the Third World, New Jersey: Pricenton University Press.

-, 1984, Public Policy Implementing, Jai Press Inc, London-England.

Goggin, Malcolm L et al. 1990. Implementation, Theory and Practice: Toward a Third Generation, Scott, Foresmann and Company, USA.

Gregory, Jackson. 2009 : “Actors and Institutions", di unduh melalui www.bath.ac.uk/management/research/pdf (12/17/17)

Hudson, Valerie M. 2005: Foreign Policy Analysis: "Actor-Specific Theory and the Ground of International Relations".

Law, J. (1992). Notes on the theory of the actor-network: Ordering, strategy, and heterogeneity. Systems Practice, 5(4), 379-393. Google Scholar, $\underline{\text { Crossref }}$

Law, John. 2007 :“Actor Network Theory and Material Semiotics”.

Leach,R and Percy J-Smith, 2001. Local Governance in Britain, Basingstoke: Palgrave Mazmanian, Daniel A and Paul A. Sabatier. 1983. Implementation and Public Policy, Scott Foresman and Company, USA.

1981. Effective Policy Implementation, Lexington Mass DC; Heath.

Muhdi, 2012, "Model implementasi kebijakan pendidikan Kota Semarang pada era otonomi daerah”. JMP. Volume 1.Nomor 2. Agustus.

N Lee, S Brown, 1994 : “Otheness and the Actor Network”. American Behavioral Scientist, Journals,Sagepub.com

Nugroho, Riant. 2006. Kebijakan Publik Untuk Negara-negara Berkembang: Modelmodel Perumusan, Implementasi dan Evaluasi. Gramedia. Jakarta.

Pressman, J.L Aaron Wildavsky, 1978. Implementation: How Great Expectation. Washington Are Dashed In Oakland. London: California Press

Peraturan Daerah Nomor 4 Tahun 2009, Tentang Penyelenggaraan Pendidikan di Kota Mataram.

Peraturan Daerah Kota Mataram Nomor 4 Tahun 2008, Tentang Pemerintahan yang menjadi Kewewnangan Pemerintahan Daerah Kota Mataram.

Sabatier, Paul. 1986. "Top down and Bottom up Approaches to Implementation Research" Journal of Public Policy 6, (Jan), h. 21-48. 
Scioli, Vaupel, James W., Frank P., Jr., and Cook, Thomas J.,1976 : "Methodologies for Analyzing Public Policies" (Book Review), Policy Analysis, 2:2 (Spring) p.363

Tjokroamidjojo, Bintoro. 2000. Good Governance, Paradigma Baru Manajemen Pembangunan. Jakarta. UI. Press.

Van Meter, D.S and C.E Van Horn, 1978. The Policy Implementation Process, A conceptual Frame work Administration and society.

World Bank. 1998. Education in Indonesia: from crisis to recovery. Washinton, D.C. Education Sector Unit, East Asia and Pacific Regional Office. 